\title{
II
}

\section{The object of property}

Предмет права собственности 



\section{Юлия МАнзулА}

\section{Объекты государственной собственности}

Вопрос о значимости, необходимости такого института, как институт права собственности имеет глубокие исторические корни. В римском праве, с точки зрения содержания, право собственности определялось как право пользования, приобретения плодов, потребления вещи (jus utendi, fruendi et abutendi) и распоряжения ею (jus disponendi). Владение же (possessio) юридически отличалось от собственности: собственник являлся владельцем, но не в силу права собственности, а как лицо, имеющее фактическую власть над вещью, и в этом отношении он ничем не отличался от других владельцев, даже недобросовестных. Поэтому главное, что характеризует правомочия собственника, - это возможность осуществлять их по своему усмотрению (ГК РФ - Гражданский кодекс Российской Федерации ${ }^{1}$, т.е. самому решать, что делать с принадлежащим имуществом, руководствуясь исключительно собственными интересами, совершая в отношении этого имущества любые действия, не противоречащие закону и иным правовым актам и не нарушающие прав и законных интересов других лиц.

Право - неотъемлемая часть законодательства любого развитого государства. в любой правовой системе общества выступает как один из центральных правовых институтов. Оно юридически закрепляет и регулирует экономические отношения присвоения имущества отдельными лицами.

По мнению советского юриста, профессора О.А. Красавчикова, государство является специфическим субъектом гражданского права. Эта специфика проявляется в том, что государство заключает в себе единство политического и хозяйственного руководства страной, единство власти суверена и собственника, представляющего в своем лице весь народ ${ }^{2}$. Именно поэтому, государство как субъект права собственности является интересным для исследования, т.к. оно является с одной стороны публич-

1 С3 РФ. 1994 № 32, Ст. 3301.

2 О.А. Красавчикова, ред., Советское гражданское право в 2-х т., t. 1, Москва 1985, C. $172-173$. 
но-правовым образованием, а с другой - субъектом гражданских прав, выступающим равноправным участником в гражданско-правовых отношениях.

Государство, как и любой другой участник правоотношений, регулируемых гражданским законодательством, самостоятельно, по своему усмотрению осуществляет принадлежащие ему субъективные права, среди которых особое место занимает право собственности. Особенности содержания права собственности государства на принадлежащее ему имущество предопределяют специфику его осуществления, поэтому обратимся к их анализу.

Ученые определяют право государственной собственности как возможность публично-правовых образований в строгом соответствии с законом и иными правовыми актами совершать в отношении имущества, которое является объектом данного права, действия, направленные на обеспечение реализации функций указанных образований. С объективной же точки зрения право государственной собственности - система правовых норм, регулирующих отношения по владению, пользованию и распоряжению государственным имуществом в целях осуществления государством своих функций.

Систему права государственной собственности, согласно ст. 214 Гражданского кодекса РФ составляют два ее вида: государственной собственностью в Российской Федерации является имущество, принадлежащее на праве собственности Российской Федерации (федеральная собственность), и имущество, принадлежащее на праве собственности субъектам Российской Федерации - республикам, краям, областям, городам федерального значения, автономной области, автономным округам (собственность субъекта Российской Федерации). Земля и другие природные ресурсы, не находящиеся в собственности граждан, юридических лиц либо муниципальных образований, также являются государственной собственностью.

Проанализировав норму подп. в п. 1 ст. 72 Конституции РФ можно сделать вывод, что разграничение государственной собственности находится в совместном ведении Российской Федерации и субъектов РФ. В силу ст. 214 ГК РФ отнесение государственного имущества к федеральной собственности и к собственности субъектов Российской Федерации осуществляется в порядке, установленном законом. А до его принятия действует Постановление Верховного Совета РФ от 27.12.1991 № 3020-1:

О разграничении государственной собственности в Российской Федерации на федеральную собственность, государственную собственность республик в составе Российской Федерации, краев, областей, автономной области, автономных округов, городов Москвы и Санкт-Петербурга и муниципальную собственность ${ }^{3}$.

3 Ведомости Съезда народных депутатов РФ и Верховного Совета РФ 1992. № 3, Ст. 89. 
Данным Постановлением определены следующие группы объектов:

- объекты, относящиеся исключительно к федеральной собственности, независимо от того, на чьем балансе они находятся, и от ведомственной подчиненности предприятий. В данную группу включены объекты, составляющие основу национального богатства страны; объекты, необходимые для обеспечения функционирования федеральных органов власти и управления и решения общероссийских задач; объекты оборонного производства; объекты отраслей, обеспечивающих жизнедеятельность народного хозяйства России в целом и развитие других отраслей народного хозяйства; прочие объекты;

- объекты федеральной собственности, которые могут передаваться в государственную собственность субъектов РФ;

- объекты, относящиеся к муниципальной собственности;

- объекты, не указанные в Приложениях 1 - 3, независимо от того, на чьем балансе они находятся, и от ведомственной подчиненности предприятий, передаются в государственную собственность субъектов Федерации. До момента определения соответствующего собственника они относятся к федеральной собственности.

Гражданским законодательством также определяются виды имущества, которые могут находиться только в государственной или муниципальной собственности (п. 3 ст. 212 ГК РФ) и устанавливается ответственность Российской Федерации, ее субъектов и муниципальных образований по своим обязательствам. В соответствии со ст. 126 ГК РФ Российская Федерация или субъект РФ отвечают по своим обязательствам, принадлежащим им на праве собственности имуществом, кроме имущества, которое закреплено за созданными ими юридическими лицами на праве хозяйственного ведения или оперативного управления, а также имущества, которое может находиться только в государственной собственности. При этом Российская Федерация, а также субъекты РФ не отвечают по обязательствам созданных ими юридических лиц, кроме случаев, предусмотренных законом. Так, например, в силу ст. 120 ГК РФ бюджетное учреждение отвечает по своим обязательствам находящимися в его распоряжении денежными средствами. При недостаточности указанных денежных средств субсидиарную ответственность по обязательствам такого учреждения несет собственник его имущества.

Управление государственной собственностью осуществляется с помощью двух вещных прав - хозяйственного ведения и оперативного управления.

Право хозяйственного ведения - это право владеть, пользоваться и распоряжаться имуществом публичного собственника в пределах, установленных законом или иными правовыми актами. Субъектами права хозяйственного ведения являются государственные или муниципальные унитарные предприятия, за исключением казенных предприятий, обладающих правом оперативного управления на закрепленное за ними 
130 | Adam Mickiewicz University Law Review

имущество. Объектом данного права является имущественный комплекс (ст. 132 ГК РФ), находящийся на балансе предприятия как самостоятельного юридического лица.

Под правом оперативного управления понимается право владеть, пользоваться и распоряжаться закрепленным за ним имуществом собственника в пределах, установленных законом, в соответствии с целями его деятельности и назначением имущества. Субъектами права оперативного управления являются казенные предприятия и учреждения. Объектами права оперативного управления является имущество, закрепленное собственником за казенными предприятиями и учреждениями, а также имущество, приобретенное ими в процессе хозяйственной деятельности.

Многонациональный народ России является носителем и единственным источником власти, которую он осуществляет непосредственно или через органы государственной власти (п. 1, 2 ст. 3 Конституции РФ). В п. 3 ст. 214 ГК РФ предусмотрено, что от имени Российской Федерации и ее субъектов права собственника осуществляют органы государственной власти в рамках их компетенции, установленной актами, определяющими статус этих органов. Компетенция является формой правосубъектности органов, осуществляющих функции управления. Специфика объектов управления и целей органов управления существенно отражается на содержании их компетенции. Однако следует отметить, что компетенция государственных органов по осуществлению права государственной собственности носит особый характер. Она вытекает из вещно-правовой сущности права хозяйственного ведения и права оперативного управления, поскольку некоторые имущественные права унитарные предприятия реализуют с согласия государственного органа, осуществляющего контроль или надзор за деятельностью юридического лица.

Парламент, согласно своей компетенции, путем принятия закона устанавливает общий порядок распоряжения тем или иным объектом либо запрещает отчуждение определенных объектов. Так, Федеральным законом от 25.06.2002 № 73-ФЗ Об объектах культурного наследия (памятниках истории и культуры) народов Российской Федерации ${ }^{4}$ установлено, что такие объекты, включенные в Список всемирного наследия, историко-культурные заповедники и объекты археологического наследия отчуждению из государственной собственности не подлежат. Парламент также вправе принять закон об особенностях распоряжения конкретным объектом. Своим законом он вправе делегировать право распоряжения федеральной собственностью Правительству РФ. Это правомочие, получаемое от парламента, следует отличать от конституционного положения, предоставляющего Правительству РФ право осуществлять управление федеральной собственностью (подп. 2 п. 1 ст. 114 Конституции РФ).

4 С3 РФ 2002. № 26, Ст. 2519. 
Все сказанное позволяет утверждать, что право государственной собственности регулируется нормами конституционного, гражданского, административного, бюджетного и земельного законодательства.

Итак, право государственной собственности имеет многоуровневую структуру, и его осуществление производится как органами государственной власти, так и унитарными предприятиями и учреждениями, которые выступают в форме юридических лиц. Самостоятельность любого государственного органа и организации в осуществлении правомочий собственности носит относительный характер и зависит от законодательного урегулирования отношений государственной собственности.

Таким образом, в рамках единого права государственной собственности приоритет отдается власти собственника, а само унитарное предприятие, особенно казенное, является скорее объектом управления, а не лицом, самостоятельно осуществляющим права владения, пользования и распоряжения закрепленным за ним имуществом в пределах, определяемых в соответствии с Гражданским кодексом РФ.

Сопоставление норм гл. 5 и п. 3 ст. 214 ГК РФ позволяет сделать вывод о том, что осуществление права собственника от имени его субъектов органами и лицами, указанными в ст. 125 ГК РФ, сводится к приобретению, осуществлению гражданских прав и обязанностей, осуществлению представительства в суде.

Российская Федерация, субъекты РФ управляют своим имуществом либо решая вопросы о создании, реорганизации и ликвидации унитарных предприятий и учреждений, либо передавая свое имущество в пользование и владение, либо разрешая приватизировать его. Осуществление права государственного собственника имеет более широкое содержание, и оно по существу отождествляется с управлением государственным имуществом. Последнее проявляется и в действиях по распоряжению имуществом, закрепленным за унитарными предприятиями и учреждениями. Так, с согласия собственника осуществляется распоряжение вкладом (долей) в уставном (складочном) капитале хозяйственного общества или товарищества, а также акциями, принадлежащими унитарному предприятию (п. 2 ст. 6 Федерального закона от 14.11.2002 № 161-Ф3 О государственных муниципальных унитарных предприятиях ${ }^{5}$ ).

Постановление Верховного Совета РФ от 27.12.1991 № 3020-1 утвердило перечень имущества, относящегося к федеральной собственности, собственности субъектов Федерации и к муниципальной собственности. Так, например, исключительно к федеральной собственности были отнесены ресурсы континентального шельфа, территориальных вод и морской экономической зоны Российской Федерации, охраняемые или особым образом используемые природные объекты (заповедники, в том числе биосферные, национальные природные парки, курорты, а также заказники, имеющие общереспубликанское значение), объекты историко-культурного и природного наследия

5 СЗ РФ 2002. № 48, Ст. 4746. 
и художественные ценности, учреждения культуры общероссийского значения, расположенные на территории РФ, государственная казна РФ (средства республиканского бюджета РФ, золотой запас). Рассмотрим подробно некоторые их них.

Недра - часть земной коры, расположенной ниже почвенного слоя, а при его отсутствии - ниже земной поверхности и дна водоемов и водотоков, простирающейся до глубин, доступных для геологического изучения и освоения. Участки недр (используемые и неиспользуемые) находящиеся в пределах территории Российской Федерации и ее континентального шельфа, составляют государственный фонд недр. При этом добытые из недр полезные ископаемые и иные ресурсы по условиям лицензии могут находиться в федеральной собственности, собственности субъектов Российской федерации, муниципальной, частной и иных формах собственности.

Согласно ст. 1.1. Закона РФ от 21.02.1992 № 2395-1 О недрах 6 , недра, включая подземное пространство и содержащиеся в них полезные ископаемые, энергетические и иные ресурсы, являются объектом исключительной государственной собственности и не могут быть предметом купли-продажи, дарения, наследования, залога или отчуждения в иной форме. Вопросы владения, пользования и распоряжения недрами находится в совместном владении РФ и субъектов РФ (ст. 72 Конституции РФ, ч. 2 ст. 2. Закона РФ О недрах).

Земля. В федеральной собственности, согласно ст.17 Земельного кодекса РФ от 25.10.20017, находятся земли:

- которые признаны таковыми федеральными законами:

- право собственности Российской Федерации на которые возникло при разграничении государственной собственности на землю;

• которые приобретены Российской Федерацией по основаниям, предусмотренных гражданским законодательством.

В собственности субъектов РФ находятся земельные участки:

- которые признаны таковыми федеральными законами;

- право собственности субъектов РФ на которые возникло при разграничении государственной собственности на землю;

- которые приобретены субъектами РФ по основаниям, предусмотренным гражданским законодательством.

В собственности субъектов РФ могут находиться также не предоставленные в частную собственность участки:

- занятые недвижимым имуществом, находящимся в собственности субъектов РФ;

6 СЗ РФ 1995. № 10, Ст. 823.

7 СЗ РФ 2001. № 44, Ст. 4147. 
- предоставленные органам государственной власти субъектов РФ, государственным унитарным предприятиям и государственным учреждениям, созданным органами государственной власти субъектов РФ;

- отнесенные к землям особо охраняемых природных территорий регионального значения, землям лесного фонда, водного фонда.

Гражданский кодекс РФ в п. 1 ст. 262 выделяет отдельную категорию участков, с особым правовым режимом - земельные участки общего пользования, на которых граждане имеют право находиться и использовать имеющиеся на этих участках природные объекты, в пределах, допускаемых законом, иными нормативными актами и собственником.

Водные ресурсы. Согласно ст. 8 Водного кодекса РФ от $3.06 .2006^{8}$ в нашей стране водные объекты находятся в собственности Российской Федерации (федеральной собственности), за исключением прудов и обводненных карьеров, расположенных в границах земельного участка, принадлежащего на праве собственности субъекту РФ, муниципальному образованию, физическому лицу, юридическому лицу, которые находятся соответственно в собственности субъекта РФ, муниципального образования, физического лица, юридического лица, если иное не установлено федеральными законами.

Леса и лесные богатства. Все леса, за исключением лесов, расположенных на землях обороны и землях населенных пунктов, а также земли лесного фонда, непокрытые лесной растительностью образуют лесной фонд. В соответствии со ст. 8 Лесного кодекса РФ от 29.01.1997 в состав земель лесного фонда входят лесные земли и нелесные земли.

К лесным землям относятся земли, покрытые лесной растительностью и не покрытые ею, но предназначенные для ее восстановления (вырубки, гари, редины, пустыри и иные). К нелесным землям относятся земли, предназначенные для нужд лесного хозяйства (земли, занятые просеками, дорогами, сельскохозяйственными угодьями и др.), а также иные земли, расположенные в границах лесного фонда (земли, занятые болотами, каменистыми россыпями, и другие неудобные для использования земли).

Согласно ст. 19 Лесного кодекса РФ лесной фонд и расположенные на землях обороны леса находятся в федеральной собственности. В соответствии с федеральными законами допускается передача части лесного фонда в собственность субъектов РФ.

В федеральной собственности находится и имущество, которое при определенных условиях, например при обращении взыскания по требованиям кредиторов, может переходить в собственность других лиц. К этой категории следует, например, отнести 
134 | Adam Mickiewicz University Law Review

имущество государственной казны РФ, состоящее из средств федерального бюджета и внебюджетных фондов, золотого запаса, алмазного и валютного фондов и имущества Центробанка, а также имущество, находящееся в государственном резерве.

Подводя итог всему вышеизложенному, можно сказать, что государство, как и любой другой участник отношений, регулируемых гражданским законодательством, самостоятельно, по своему усмотрению реализует принадлежащие ему субъективные права, среди которых важное место занимает право собственности. Но в отличие от физических и юридических лиц осуществление государством права собственности отличается рядом особенностей, зависящих от содержания и объекта этого права, и происходит в особых правовых формах.

\section{Биографическая аннотация:}

Юлия Манзула - Иркутский государственный университет, Юридический институт. Научные интересы: гражданское право, гражданский и арбитражный процесс.

\section{SUMMARY}

\section{The objects of the state property}

The study aims at an evaluation of the state property right in the context of its object. The author analyse the features of the state property right according to the object it is related to. KEYwORDS: the state property, the object of the state property, civil law 